\title{
Kewenangan Hakim untuk Melakukan Intervensi : terhadap Kewajiban Kontraktual Berdasarkan Âsas Iktikad Baik
}

Ridwan Khairandy

\begin{abstract}
Under the article 1338, section 3 of Civil Law Code, it is stated that an agreement should be implemented on the basis of goodwill because it is one of the important principles in Contract Law. However, the notion of goodwill is so abstract that it is whether related to a matter of law or moral. This article will propose a description of the goodwill -when and where it is coming up-, its functions in implementing the agreement, and how the authorities of the judge to get involved towards the contract duties on the strength of the goodwill principles.
\end{abstract}

\section{Pendahuluan}

Seiring dengan makin berpengaruhnya pemikiran laissez faire di bidang ekonomi, kebebasan berkontrak menjadi prinsip yang umum dalam mendukung persaingan bebas. Kebebasan berkontrak menjadi penjelmaan hukum (legal expression) prinsip pasar

bebas: ${ }^{1}$. Setiap campur tangan negara terhadap kontrak bertentangan dengan pasar bebas. ${ }^{2}$ Dalam perkembangannya, ternyata kebebasan berkontrak bukanlah kebebasan tanpa batas. ${ }^{3}$ Kebebasan berkontrak yang diiringi asas pacta sunt servanda dalam

'Seiring dengan itu, inti permasalahan hukum kontrak lebih tertuju kepada realisasi kebebasan berkontrák. Lihat Konrad Zweight dan Hein Kotz. 1987. Introduction to Comparative Law Volume II- The Institution of Private Law. Oxford: Clarendon Press. HIm 8. Lihatjuga Henry R. Cheseeman. 1995. Business Law: The Legal, Ethical, and International Environment. New Jersey: Prentice Hall. HIm 159.

${ }^{2}$ Morton J. Horwitz. 1992. The Transformation of American Law 1870 - 1960 The Crisis of Legal Orthodoxy. Oxford: Oxford University Press. HIm 33.

${ }^{3}$ Perhatikan M. Yahya Harahap. "Dua Sisi Putusan Hakim Tidak Adil bagi yang Kalah dan Adil bagi yang Menang." Varia Peradilan. Tahun VIII No. 95 (Agustus 1993). HIm 107. 
kenyataannya dapat menimbulkan ketidakadilan. Kebebasan berkontrak harus didasarkan pada keseimbangan posisi tawar (bargaining position), ${ }^{4}$ tetapi dalam kenyataannya para pihak tidak selalu memiliki posisi tawar yang seimbang. ${ }^{5}$ Akibatnya, pihak yang memiliki posisi tawar lebih kuat cenderung menguasai pihak yang memiliki posisi tawar lebih lemah. Akhirnya, negara kemudian melakukan sejumlah pembatasan kebebasan berkontrak baik melalui peraturan perundang-undangan maupun putusan pengadilan: 6 Pembatasan . kebebasan berkontrak tersebuit setidak-tidaknya dipengaruhi oleh dua faktor, yakni:?

1. Makin berpengaruhnya ajaran iktikad baik, di mana iktikad baik tidak hanya ada pada pelaksanaan perjanjian, tetapi juga sudah harus ada pada saat dibuatnya perjanjian, ${ }^{8}$

4A.G. Guest (ed). 1983. Chity on Contract, Volume / General Principles. London: Sweet \& Maxwell. HIm 3. Lihat Juga Subekti. 1976. Aspek-Aspek Hukum Perikatan Nasional. Bandung: Alumni. Hlm 12.

${ }^{5}$ Konrad Zweight dan Hein Kotz. Op.Cit. Hlm 9. Lihat Juga Z. Asikin Kusumah Atmadja (ed). 1992. Beberapa Yurisprudensi Perdata yang Penting serta Hubungan Ketentuan Hukum Acara Perdata. Jakarta: Mahkamah Agung Republik Indonesia. HIm. 367. Lihat juga J. Satrio. 1995. Hukum Perikatan, Perikatan Yang Lahir dari Perjanjian Buku II. Bandung: Citra Aditya Bakti. HIm 149.

ELihat Peter Gillies. 1993. Business Law. Sydney: The Federation Press. HIm 117. Lihat juga John D. Calamary dan Joseph M. Perillo. 1977. Contracts. West Publishing Co: St. Paul, Minn. HIm 6. Khusus yang berkaitan dengan pengadilan M. Yahya Harahap menyatakan, apabila di dalam suatu perjanjian berhadapan pihak ekonomi kuat dengan pihak ekonomi kuat, hakim dapat melakukan matigingrecht. Dalam arti hakim berwenang menafsirkan perjanjian itu ke arah pemulihan (restorasi) dengan cara mengurangi hal-hal yang melampaui batas dalam perjanjian. Lihat M. Yahya Harahap. Loc.Cit.

'Bandingkan dengan Setiawan. 1992. Anoka Masalah Hukum Hukum dan Hukum Acara Perdata. Bandung: Alumni. HIm 179 - 180. Menurut Setiawan, pembatasan kebebasan berkontrak dipengaruhi berkembangnya doktrin iktikad baik, berkembangnya doktîn penyalahgunaan keadaan, makin banyaknya kontrak baku, dan berkembangnya hukum ekonomi. Bandingkan pula dengan pendapat Purwahid Patrik. Terjadinya berbagai pembatasan kebebasan berkontrak karena (1) berkembangnya dalam lapangan ekonomi yang membentuk persekutuan-persekutuan dagang, badan-badan hukum atau perseroan-perseroan, dan golongan-golongan masyarakat lain (misalnya golongan buruh dan tani); (2) terjadinya pemasyarakatan (vermaatschappelijking) keinginan adanya keseimbangan antara individu dan masyarakat yang tertuju kepada keadilan sosial; (3) timbulnya formalisme perjanjian; (3) makin banyak peraturan di bidang hukum tata usaha negara. Lihat Purwahid Patrik, Asas Iktikad Baik dan Kepatutan dalam Perjanjian, (Semarang: Badan Penerbit Universitas Diponegoro, 1986), hlm 9-10. Bandingkan juga dengan pendapat Sri Soedewi Maschoen Sofwan. Menurut dia pembatasan kebebasan berkontrak akibat adanya: (1) perkembangan masyarakat di bidang sosial ekonomi, misalnya karena adanya penggabungan atau sentralisasi perusahaan; (2) adanya campur tangan pemerintah untuk melindungi kepentingan umum atau pihak yang lemah; dan (3) adanya aliran dalam masyarakat yang menginginkan kesejahteraan sosial. Lihat Djohari Santoso dan Achmad Ali. 1983. Hukum Perjanjian Indonesia. Yogyakarta: Badan Penerbit FH Ull. HIIm 53-54.

"Lihat Nili Cohen. "Pre-Contractual Duties: Two Freedoms and the Contract to Negotiate", Jack Beatson dan Daniel Friedmann (eds). 1995. Good Faith and Fault in Contract Law. Oxford: Clarendon Press. Him 28 dan $30-31$ 
2. makin berkembangniya ajaran penyalahgunaan keadaan (misbruik.van omstandigheiden atau undue influence;

Iktikad 'bäik yang menjadi asas penting dalam hukum kontrak yang dapat membatasi asas kebebasan berkontrak dan asas pacta sunt servanda, dalam penerapannya masih menimbulkan sejumlah permasalahan, yäkni:

1. Iktikad baik merủpakan pengertian yang abstrak, sehingga dalam penerapannya masih memerlukan penafsiran hakim; ${ }^{10}$

2. Pengaturan iktikad baik yang terdapat di dalam: Kitab Undang-Undang Hukum Perdata Indonesia hanya mencakup iktikad baik dalam peläksanaan kontrak, padahal iktikad seharusnya sudah ada pula pada saat negosiasi dan penyusunan kontrak.

\section{Konsensualisme, Kebebasan Berkontrak, dan Kekuatan Merigikatnya Kontrak}

Di dalam hukum kontrak dikenal tiga asas yang satu dengan lainnya saling berkaitan, yakni asas konsensualisme (the principle of consensualism), asas kekuatan mengikatnya kontrak (the principle of the binding force of contract); dan' asas kebebasan berkontrak (principle of freedom of contract). ${ }^{11}$

Dengan asas konsensualisme, kontrak dikatakan telah lahir jika telah ada kata sepakat atau persesuaian kehendak di antara para pihak yang membuat kontrak tersebut. Asas konsensualisme ini berkaitan dengan penghormatan martabat manusia. Subekti ${ }^{12}$ menyatakan bahwa hal inị merupakan puncak peningkatän martabat manusia yang tersimpul dari pepatah Belanda, "een man een word, een word een man", yang maksudnya dengan diletakkànnya perkataan seseorang, orang itu ditingkatkan martabatnya sebagai manusia.

Dasar teoritik mengikatnya kontrak bagi para pithäk yang umumnya dianut di negaranegara hukum sipil (civil law countries) dikembangkan oleh para postglossator pada. abad keempat beläs. ${ }^{13}$ Konsep ini tidak hanya menjadi dasar ilmu hukum Romawi pada abad keduabelas dan ketigabelas sebagaimana dikembangkan glossator melalui konsep, kategori, dan definisi

\footnotetext{
${ }^{9}$ Bandingkan dengan P.P.C. Haanappel dan Ejan Mackaay. 1990. Nieuw Nederlands Burgerilik Wetboek, Het Vermogensrecht. Deventer: Kluwer. HIm 26. Dia menerjemahkan istilah misbruik van omstandigheiden ke dalam bahasa Inggris dengan istilah abuse of circumtances. O.A. Häzen menyatakan bahwa istilah yang sepadan dengan undue influence adalah misbruik van omstandigheiden. Lihat $O$.A. Hazen. "The Principle of Gross Disparity en Misbruik van Omdstandigheiden." M.E. Ranke, et.al. (eds). 1995. Europees Contracten. Arnhern: Gouda Quint. HIm 13.

${ }^{10}$ Lihat Martijn Hesselink. "Good Faith." Arthur Haartkamp et.al (eds). 1998. Toward a European Civil Code. The Hague: Kluwer. HIm 289 dan 300-301. Perhatikan juga Matthias Storne."The Binding Character of Contracts - Causa and Consideration." Ibid. HIm 248-249.

"Arthur S. Hartkamp dan Marianne:M.M. Tillema. 1993. Contract in the Netherlands. Deventer: Kluwer: $\mathrm{HIm} 34$.

12Subketi. Loc.Cit.

${ }^{13}$ Harold J. Berman. 1999. Law and Revolution; The Formation of Western Legal Tradition. Cambridge: Harvard University Press. HIm 246.
} 
Aristoteles, tetapi juga menjadi dasar ilmu hukum dan sistem hukum pada abad keduabelas dan ketigabelas yang dipengaruhi hukum kanonik. ${ }^{14}$ Hukum kanonik menambah beberapa prinsip sistem hukum perjanjian Romawi. Pertama, prinsip mengikatnya janji bagi mereka atau para pihak yang membuatnya. ${ }^{15}$ Kedua, janji merupakan kausa dasar kontrak. ${ }^{16}$ Jika hal itu merupakan kausa yang pantas (proper), maka ia memberikan

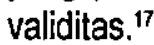

Hukum kanonik dimulai dari prinsip disiplin penitisial bahwa setiap janji itu mengikat. ${ }^{18}$ Dari sinilah lahir prinsip pacta sunt servada. ${ }^{19}$ Oleh karenanya, tidaklah penting artinya apakah suatu perbuatan di dalam kontrak tidak dalam tulisan ataukah tidak dengan sumpah: Suatu sumpah dan suatu janji tanpa sumpah adalah sama dalam pandangan Tuhan; dan tidak ada kewajiban untuk memenuhi janji jika janji itu sama dengan dusta. ${ }^{20}$

Dengan adanya janji timbul kemauan bagi para pihak untuk saling berprestași, ada kemauan untuk saling mengikatkan diri..1 Kewajiban kontraktual tersebut menjadi sumber bagi para pihak secara bebas menentukan isi kontrak dengan segala akibat hukumnya. Berdasarkan kehendak tersebut, para pihak secara bebas mempertemukan kehendak mereka. masing-masing. ${ }^{22}$, Kehendak para pihak inilah yang menjadi dasar kontrak. Terjadinya perbuatan hukum itu ditentukan berdasar kata sepakat (konsensualisme). ${ }^{23}$

Dengan adanya konsensus dari para pihak, maka kesepakatan itu menimbulkan kekuatan mengikat perjanjian sebagaimana

\footnotetext{
$14 /$ bid.

is/bid. HIm.. 247.

${ }^{18} /$ bid.

${ }^{17} /$ bid.

${ }^{18} /$ bid.
}

19Lengkapnya adalah pacta nuda servanda sunt. Makna asalnya adalah bahwakata sepakat itu tidak perlu diumuskan dalam bentuk sumpah, perbuatan, atau formalitas tertentu agar perjanjian itu mengikat. Lihat Sudikno Mertokusumo. 1999. Mengenal Hukum. Yogyakarta: Liberty. HIm. 112. Grotius mencari dasar konsensus itu pada pacta sunt servanda (janji itu mengikat). Selanjutnya ia menyatakan: "promissorum implemndonum obligatio" (kita memenuhi janji kita). Lihat Mariam Darus Badrulzaman. Op.Cit K.U.H.Perdata Buku III .... HIm. 109. Lihat juga Hari Chand. 1994. Modern Jurisprudence. Kuala Lumpur: International Law Book Services. HIm. 43.

${ }^{20}$ Harold J. Berman. Loc.Cit.

${ }^{21}$ Kemauan tersebut membangkitkan kepercayaan (vertrouwen) bahwa perjanjian itu dipenuhi. Asas kepercayaan ini merupakan nilai etis yang bejsumber pada moral. Manusia terhormat kata Eggens adalah manusia yang memegang janjinya. Lihat Mariam Darus Badrulzaman. Loc.Cit. Di bagian yang sama Mariam Darus Mabdrulzaman mensitir pantun Melayu yang menyatakan: "Kerbau dipegang talinya, manusia dịpegang janjinya".

22Donald Haris dan Dennis (eds). 1989. Contract Law Today: Anglo French Comparation. Oxford: Clarendon Press. Hlm. 17.

${ }^{23} \mathrm{Jbid}$. HIm. 40. 
layaknya undang-undang (pacta sunt servanda). ${ }^{24}$ Apa yang dinyatakan seseorang dalam suatu hubungan hukum menjadi hukum bagi mereka (cum nexum faciet mancipiumque, uti lingua mancuoassit, ita jus esto). ${ }^{25}$ Asas inilah yang menjadi kekuatan mengikatnya perjanjian (verbindende kracht van de overeenkomst). ${ }^{26}$ Ini bukan saja kewajiban moral, tetapi juga kewajiban hukum yang pelaksanaannya wajib ditaati. ${ }^{27}$ Sebagai konsekuensinya, maka hakim maupun pihak ketiga tidak boleh mencampuri isi perjanjian' yang dibuat para pihak tersebut. ${ }^{28}$

Dengan asas kebebasan berkontrak setiap orang diakui memiliki kebebasan untuk membuat kontrak dengan siapapun juga, menentukan isi kontrak, menentukan bentuk kontrak, memilih hukum yang berlaku bagi kontrak yang bersangkutan. Jika asas konsensualisme berkaitan dengan lahirnya kontrak, asas kekuatan mengikatnya kontrak berkaitan dengan akibat hukum, maka asas kebebasan berkontrak berkaitan dengan isi kontrak.
Ketiga asas tersebut ditarik dari doktrin hukum kontrak klasik yang berkembang di Perancis (doctrine of the autonomy of the will) dan Inggris (doctrine of concensus ad idem dan laissez faire).

Menurut doktrin klasik kontrak Perancis, kontrak berkaitan dengan kemauan bebas (free will). Kontrak merupakan manisfestasi kemauan bebas para pihak. Sebagaimana halnya dengan legislasi yang merupakan manisfestasi kemauan negara, kontrak juga merupakan suatu hukum khusus yang dibuat para pihak sendiri yang menghubungkan kehendak mereka. ${ }^{29}$ Otonomi kehendak bermakna bahwa para pihak memiliki kehendak untuk menentukan hukumnya sendiri, kewajiban kontraktual bersumber dari kehendak para pihak sendiri dan secara bebas - menciptakan kontrak dengan segala akibat hukumnya. ${ }^{30}$ Kehendak para pihak inilah yang menjadi dasar atau fondasi kontrak Doktrin otonomi kehendak tersebut menekankan kebebasan individu untuk membuat kontrak tidak bernama (onbenoemde, innominaat

${ }^{24}$ Perhatikan Pasal 1338 ayat (1) Kitab Undang-Undang Hukum Perdata Indonesia yang menyatakan: Semua perjarijian yang dibuat secara sah berlaku sebagai undang-undang bagi mereka yang membuatnya (alle wettigiglijk gemaakte overeenkomsten strekken dengenen die dezelve hebben aangegaan to wet)".

${ }^{25}$ Lon L. Fuller dan Melvin Aron Eisenberg. 1972. Basic Contract Law. West Publishing Co: St. PaulMinn. HIm. 112.

${ }^{26} F r e d$ B.G. Tumbuan. "Kekuatan Mengikat Perjanjian dan Batas-Batasnya". Makalah, Jakarta (Juli 1988). HIm. 1.

${ }^{27}$ /bid.

${ }^{28}$ Djohari Santoso dan Achmad Ali. Op.Cit. HIm. 49.

${ }^{29}$ Bary Nicholas. "Introduction to the French Law of Contract." Donald Harris dan Denis Tallon (eds). Op.Cit. HIm 17.

${ }^{30}$ Georges Rouhette. "The Obligatory Force of Contract in French Law." Ibid. Him.19. 
contracten). Sepanjang tidak bertentangan dengan ketertiban umum, para pihak bebas untuk mëmbuat kontrak yang mereka inginkan. ${ }^{31}$

Di Inggris dan Amerika selama abad kesembilanbelas para hakim dan akademisi hukum menolak ajaran yang telah ada yang mendasarkan kewajiban kontraktual diderivasi dari keadilan atau kewajaran dalam suatu "exchange". Sumber kewajiban kontraktual adalah bertemunya kehendak atau kemauan para pihak. ${ }^{32}$ Jadi, kontrak juga ditekankan pada adanya kata sepakat dari kemauan atau maksud para pihak. Dengan perkataan lain, kata sepakat menjadi hal penting dalam penyusunan kontrak (concensus ad idem). ${ }^{33}$

Doktrin kontrak yang dianut Inggris dan Amerika tersebut erat kaitannya dengan awal revolusi Inggris, dan juga pemikiran yang berkaitan dengan aliran pemikiran ekonomi klasik dan filsafat utilitarianisme Jeremy Bentham. ${ }^{34}$ Pengaruh inilah yang melahirkan ideologi free choice ${ }^{35}$ Kebebasan tersebut bermakna bahwa tidak seorangpun terikat kepada suatu kontrak jika tidak ada pilihan bebas untuk melakukan sesuatu. ${ }^{36}$ Dengan demikian kebebasan berkontrak lahir atau berasal dari dua pemikiran, yakni kontrak didasarkan kata sepakat dan-kontrak melahirkan suatu ideologi free choice yang dianggap sebagai suatu hal yang terbaik, dan mensisakan sangat sedikit peran. bagi nilainilai masyarakat. ${ }^{37}$ Hukum kọntrăk menjadi hukum pasar, dan hanya mensisakan fungsi. bagi masyarakat atau negara untuk mencegah tindakan penipuan dan pelaksanaan kontrak yang dibuat pasar. ${ }^{38}$

A.W. Coats ${ }^{39}$ menyatakan bahwa antara penganut aliran pemikiran ekonomi klasik dan utilitarian memiliki hubungan yang saling melengkapi dalam pemikiran dan tindakan aliran kebebasan yang individualistik. Keduanya percaya bahwa individualisme sebagai suatu nilai dan mekanisme sosial, mereka percaya terhadap kebebasan berkontrak sebagai suatu asas umum. Mereka menerima sebagai starting point bahwa individu pada umumnya : mengetahui kepentingan mereka sendiri yang terbaik. Keduanya memiliki perhatian utama terhadap sebesar mungkin kekayaan seseorang dan kebahagian orang lain tanpa memperdulikan bagaimana kekayaan atau kebahagian itu didistribusikan., Bagi Jeremy Bentham ${ }^{40}$.

31/bid. HIm. 18.

${ }^{32}$ Morton J. Hortwitz. 1995. The Transforation of American Law 1780 - 1860. Cambridge: Harvard University Press. Him. 160.

${ }^{33}$ P.S. Atiyah. 1981. An Introduction to the Law of Contract. Oxford: Clarendon Press. HIm. 6.

${ }^{34}$ Patrick Atiyah. "The Binding Nature of Contractual Obligations." Donald Harris dan Dennis Tallon (eds). Op.Cit. HIm. 28.

${ }^{35}$ Ibid.

${ }^{36}$ P.S. Atiyah. Op.Cit. An Introduction .... HIm. 8.

${ }^{37}$ P.S. Atiyah: Loc.Cit.

${ }^{38}$ Ibid.

${ }^{39}$ P.S. Atiyah. 1988. The Rise and Fall of Freedom of Contract. Oxford: Clarendon Press. HIm. 324.

${ }^{40} \mathrm{lbid}$. Him. 326. 
pembatasan kebebasan berkontrak adalah pembatasan terhadap kebebasan itu sendiri dan semua pembatasan terhadap kebebasan adalah jahat dan memerlukan pembeniaran untuk melakukannya.

Bagi para pelopor ekonomi laissez faire, seperti Adam Smith berkeyakinan bahwa peraturan perundang-undangan seyogyanya tidak digunakan untuk mencampuri kebebasan berkontrak, karena kebebasan berkontrak penting artinya bagi kelanjutan perdagangan industri. ${ }^{41}$ Sehubungan dengan hal tersebut, Lord Liverpool yang menjadi Perdana Menteri Inggris selama lima belas tahun (1812 - 1827) mempercayai bahwa setiap campur tangan dalam bidang ekonomi hampir selalu membawa malapetaka, dan dia umumnya tidak mau melakukan campur tangan tersebut karena melanggar "kesakralan" asas kebebasan berkontrak.

Untuk mencapai tujuan asas kebebasan berkontrak, para pihak yang mengadakan perjanjian harus memiliki posisi tawar yang seimbang. Kebebasan berkontrak yang sebenamya akan eksis jika para pihak di dalam kontrak memiliki keseimbangan secara ekonomi dan sosial. Dalam kasus Coppage $v$ Kansas, Hakim Pitney menyatakan bahwa tidak mungkin menegakkan kebebasan berkontrak tanpa pada saat yang sama ada pengakuan keseimbangan posisi tawar para pihak. ${ }^{43}$ Dalam kenyataannya, tidak selalu para pihak memiliki posisi tawar yang seimbang, sehingga dapat merugikan pihak yang memiliki posisi tawar yang lemah. Doktrin. hukum kontrak klasik memang memiliki perhatian yang sangat sedikit terhadap adanya ketidakseimbangan posisi tawar para pihak dalam kontrak. Bagi doktrin ini, kebebasan berkontrak berarti orang dapat memilih apa yang dia inginkan melalui adanya kesepakatan bersama (mutual agreement). Lahirnya pandangan tersebut dikarenakan dianut asumsi bahwa posisi tawar para pihak dalam kontrak adalah sejajar. ${ }^{44}$

Jika asas kebebasan berkontrak dan asas pacta sunt servanda dipegang teguh dapat melahirkan ketidakpatutan dan ketidakadilan dalam kontrak. Dari sinilah kemudian lahir adanya berbagai pembatasan kebebasan berkontrak dan pembatasan kekuatan mengikatnya perjanjian baik melalui peraturan perundang-undangan maupun melalui pengadilan.

Iktikad Baik sebagai Dasar Intervensi Hakim terhadap Kewajiban Kontraktual

Asas iktikad baik menjadi salah satu instrumen hukum yang dapat membatasi kebebasan berkontrak dan kekuatan mengikatnya pejjanjian. Dengan fungsi iktikad baik yang bersifat membatasi dan meniadakan, hakim dapat mengintervensi kewajiban kontraktual yang secara objektif mengandung atau bertentangan dengan

${ }^{41}$ Sutan Remy Sjahdeini. 1993. Kebebasan Berkontrak dan Perlindungan Hukum yang Seimbang bagi Para Pihak dalam Perjanjian Kredit Bank di Indonesia. Jakarta Institut Bankir Indonesia. HIm 20-21. ${ }^{42}$ P.S. Atiyah. Op.Ci. The Rise .... HIm. 507.

${ }^{43}$ Lihat Konrad Zweight dan Hein Kotz. Loc.Cit.

${ }^{44}$ P.S. Atiyah. Op.Cit. An Introduction .... Hlm. 11. 
kepatutan dan keadilan. Asas iktikad baik digunakan untuk menginterpretasi kontrak. Kontrak harus ditafsirkan sesuai dengan kepatutan dan keadilan.

Iktikad baik merupakan salah satu asas . penting dalam hukum kontrak, ${ }^{45}$ tetapi pengaturan iktikad baik di Indonesia, terutama di dalam Kitab Undang-Undang Hukum Perdata termasuk ketentuan yang paling tidak jelas. ${ }^{46}$ Pasal 1338 ayat (3) Kitab UndangUndang Hukum Perdata hanya menyebutkan perjanjian harus dilaksanakan dengan iktikad baik. Tidak ada penjelasan lebih lanjut apa yang dimaksud dengan iktikad baik tersebut: Oleh karena itu, untuk dapat memahami makna iktikad baik secara lebih baik harus dilihat pada penafsiran iktikad baik dalam praktik peradilan. Bahkan, menurut J. Satrio, ${ }^{47}$ ketentuan pengaturan iktikad baik tersebut adalah ketentuan yang ditujukan kepada pengadilan. Dikatakan demikian karena sengketa mengenai iktikad baik dalam praktiknya hampir selalu dimintakan penyelesaiannya kepada pengadilan. Dengan demikian, perkembangan doktrin iktikad baik lebih merupakan hasil kerja pengadilan daripada legislatif yang berkembang dalam kasus demi kasus. ${ }^{48}$ Hakimlah dalam hal ini yang memegang peranan penting dalam menafsirkan atau memperluas ajaran iktikad baik tersebut.

Dikatakan tidak jelas atau kabur, karena tidak ditemukan adanya pengertian dan kriteria iktikad baik di dalam peraturan perundangan dalam berbagai Kitab Undang-Undang Hukum Perdata di negara-negara hukum sipil.

Penafsiran iktikad baik oleh pengadilan muncul dalam putusan Hoge Raad di Negeri Belanda pada tanggal 9 Pebruari 1923. Menurut Hoge Raad, iktikad ini merupakan doktrin merujuk kepada kewajaran atau kepatutan dan keadilan (redelijkheid en billijkheid) yang hidup dalam masyarakat. ${ }^{49}$ Hoge Raad menyatakan bahwa perjanjian harus dilaksanakan menurut kewajaran dan keadilan (volgens de eisen van redelijkheid en billijkheid). ${ }^{50}$ Hoge Raad dengan tegas menyatakan bahwa memperhatikan iktikad baik pada pelaksanaan perjanjian tidak lain adalah menafsirkan perjanjian menurut

${ }^{45}$ Perhatikan John Swan dan Barry J Reiter. 1985. Contracts: Cases, Notes, and Materials. Canada: EmontMontgomery. HIm. 478.

${ }^{45}$ J. Satrio. 1995. Hukum Perikatan, Perikatan yang Lahir dari Perjanjian, Buku Il. Bandung: Citra Aditya Bakti. HIm. 165.

${ }^{47} \mathrm{lbid}$. HIm. 166.

${ }^{43}$ Werner F Ebke dan Bettina M Steinhauer. "The Doctrine of Good Faith in German Contract Law." Jack Beatson dan Daniel Friedmand (eds). Op.Cit. HIm 7.

${ }^{49}$ P.L. Wery, 1990. Perkembangan tentang Hukum Iktikad Baik di Nederland. Jakarta: Percetakan. Negara. Him. 11.

50/bid. Putusan Mahkamah Agung Republik Indonesia Nomor 26 K/SIP/1955 tanggal 11 Mei 1955 juga memakai istilah "pantas" dan sesuai dengan rasa "keadilan". Di Kitab Undang-Undang Hukum Perdata Belanda (Baru) tidak lagi digunakan istilah iktikad baik (te goeder trouw), digantikan dengan istilah redelijkheid en billijkheid. 
ukuran kepatutan dan keadilan. ${ }^{51}$ Dengan demikian lahir pandangan yang menyatakan bahwa Hoge Raad menyamakan iktikad baik dengan kepatutan dan keadilan.52 Penafsiran yang demikian itu erat kaitannya dengan Pasal 1375 Kitab Undang-Undang Hukum Perdata Belanda (lama) yang menyebutkan:

"Overeenkomsten verbinden niet alleen tot datgene het welk uitdrukkelijk bij dezelve bepaald is, maar ook tot al hetgeen dat, naarden aard van dezelve overeenkomsten, door de billijkheid, het gebruik, of de wet, wordt gevordered". ${ }^{53}$

Dengan penafsiran iktikad baik oleh Hoge Raad tersebut, telah ada rujukan iktikad baik harus mengacu kepada kepatutan dan keadilan, tetapi rujukan tersebut belum membuat kekaburan iktikad baik menjadi jelas. Pengertian kepatutan dan keadilan sangat abstrak dan syarat dengan perdebatan filosofis. Sejak ribuan tahun lalu hingga sekarang ini tidak ada kesepakatan mengenai arti keadilan yang dapat dijadikan definisi. ${ }^{54}$ Bänyak teori tentang keadilan yang dikembangkan oleh para ahli filsafat hukum. Dari teori keadilan yang dikembangkan Plato dan Aristoteles (ancient theory) hingga teori keadilan yang kontemporer yang dikembangkan oleh Rawls dan Hart. ${ }^{55}$ Teori keadilan yang diyakini hakim kebenarannya dapat mempengaruhi hakim menafsirkan iktikad baik, sehingga dalam praktiknya akan dapat menimbulkan penafsiran iktikad baik yang berbeda-beda. Dengan demikian, sikap pandang hakim terhadap keadilan dapat bersifat subjektif. Sikap pandang terhadap keadilan yang subjektif tersebut seharusnya dapat dihindari, karena keadilan yang dimaksud Hoge Raad di atas haruslah keadilan yang hidup di dalam masyarakat. ${ }^{56}$

Keabstrakan atau kekaburan iktikad baik tersebut dipertanyakan pula dalam perkara Gateway v Holding Lfd (1991), 106, NSR (2nd) di Kanada. Pertama, apakah doktrin iktikad baik tersebut semata-mata mengenai ketidakpastian dan moralisme hukum? Kedụa, apakah doktrin iktikad baik itu teori hukum kontrak neo klasik ? Ketiga, apakah doktrin iktikad baik adalah rule of law atau rule interpretation ${ }^{57}$ Oleh- karena itu, seringkali dipertanyakan, apakah iktikad itu hukum ataukah moral.

${ }^{51}$ J. Satrio. Op.Cit. HIm. 177.

52/bid.

${ }^{53}$ Rumusan pasal tersebut telah digantikan oleh Pasal 6: 248 ayat (1) Kitab Undang-Undang Hukum Perdata Belanda (Baru) yang menyebutkan:"een overeenkomst heeft niet alleen de door partijen overeengekomen rechisvolgen, maar die cok die welke, naar de aard van de overeenkomst, uit de de wet, gewone of de eisen van redelijkheid en billikheid voortvioien".

${ }^{54}$ James K. Feibleman. 1985. Justice, Law and Culture. Dordrecht: Matinus Nijhoff Publisher. HIm. 5.

${ }^{55}$ Lebih. lanjut lihat /bid. HIm. 173-201.

${ }^{56}$ Z. Asikin Kusumahatmadja. Op.Cit. Hlm. 359.

${ }^{5}$ Erman Rajagukguk. "Kontrak Bisnis Internasional dan Kaitannya dengan Analisis Ekonomi terhadap Kontrak. Jurnal Magister Hukum. Vol 1 No. 1 (September 1999). HIm. 4. 
Martijn Hassenlink ${ }^{58}$ menyebutkan semua iktikàd baik yang bersifat objektif59 biasanya mengacu kepada konsep normatif. Sesungguhnya iktikad baik seringkali dilihat sebagai suatu norma tertinggi dari hukum kontrak, hukum perikatan, atau bahkan hukum perdata. Iktikad baik seringkali pula dikatakan sebagai berhubungan dengan standar moral. Di satu sisi, dikatakan menjadi suatu standar moral itu sendiri, yakni suatu prinsip legalethical, sehingga iktikad baik bermakna honesty (candour, loyalti et catera). Dengan demikian, pada dasarnya iktikad baik bermakna bahwa satu pihak harus memperhatikan kepentingan pihak lainnya di dalam kontrak. Di sisi lain, iktikad baik dapat dikatakan sebagai pintu masuk hukum melalui nilai moral (moral values). Dengan keadaan yang demikian itu menjadikan iktikad baik sebagai norma terbuka (open nom), yakni suatu norma yang isinya tidak dapat ditetapkan secara abstrak, tetapi ditetapkan melalui konkretisasi kasus demi kasus dengan memperhatikan kondisi yang ada.

Mengingat ketidakjelasan kriteria iktikad baik di atas, H.G. van der Werf ${ }^{60}$ menyébutkan adanya pertentangan mengenai eksistensi asas iktikad baik tersebut. Bagi mereka yang berpikir positif, iktikad baik berguna dalam mempertahankan hak hak-hak perdatanya, karena iktikad baik dapat memberikan penyelesaian atas pertikaian perjanjian tidak melalui teknis yuridis. Artinya, iktikad baik menjadi sarana atau jembatan antara hak perdata di satu pihak sebagai sistem dogmatis yuridis, di lain pihak hak perdata sebagai sarana keadilan untuk penyelesaian sengketa dalam masyarakat. Sebaliknyà, bagi yang berpikir skeptis, iktikad baik tidak ada manfaatnya, yang digambarkan seperti kapal tanpa kemudi, dia terhempas oleh yurisprudensi. Lembaga hukum ini tidak memiliki kompas sebagai dasar untuk menguji hubungan yang timbul, juga tidak tidak memiliki arah dan tujuan.

Di dalam konteks putusan pengadilan Indonesia, tidak terlihat adanya penafsiran kepatutan dan keadilan di dalam pertimbangan hukumnya. Di dalam pertimbangan hukumnya, biasanya hakim menyatakan bahwa pembuatan atau pelaksanaan kontrak harus dilandasi iktikad baik. Tidak dijumpai adanya alasan atau kriteria adanya iktikad baik dan iktikad buruk di dalam kontrak, bahkan tidak ditemukan pula bagaimana caranya hakim menentukan ada tidaknya iktikad baik tersebut. Dalam keadaan demikian, sulit dijumpai adanya perdebatan filosofis mengenai makna dan kriteria iktikad baik yang seharusnya dibangun oleh pengadilan.

Ruang lingkup iktikad baik yang diatur dalam Kitab Undang-Undang Hukum Perdata di beberapa negara seperti di Indonesia masih diletakkan pada pelaksanaan kontrak saja. Hal itu terlihat dari bunyi Pasal 1338 ayat (3) Kitab Undang-Undang Hukum Perdata Indonesia

${ }^{58}$ Martijn Hassenlink. Op.Cit. HIm. 287.

${ }^{59}$ /ktikad baik yang bersifat objektif bermakna, melaksanakan perjanjian dengan memperhatikan norma kepatutan dan keadilan. Selain iktikad baik yang bersifat objektif, dikenal iktikad baik yang bersifat subjektif, yakni yang berkaitan dengan keadaan menguasai (bezit).

${ }^{60}$ H.G. van der Werf. 1982. Redelijkheid en Billjkheid in het Contractenrecht: Enkele Beschouwingen over Goede Trouw, Redelikheid en Billikheid in het Huidige en het Komende Contractenrecht. Arnhem: Gouda Quint BV. HIm. 12 - 13. 
yang menyatakan bahwa perjanjian harus dilaksanakan dengan iktikad baik (zij moeten te goeder trouw worden ten uitvoer gebracgf). ${ }^{61}$ Padahal sesungguhnya iktikad baik juga diperlukan di dalam proses negosiasi dan penyusunan pembuatan kontrak. Dengan demikian, iktikad baik tersebut sebenarnya sudah harus ada sejak saat proses negosiasi dan penyusunan kontrak hingga pelaksanaan. kontrak.

Pada mulanya asas iktikad sebagaimana diatur Pasal 13338 ayat (3) Kitab UndangUndang Hukum Perdata Indonesia hanya terletak di dalam pelaksanaan perjanjian: ${ }^{62}$ Di dalam perkembangannya, iktikad baik tersebut harus menguasai pula keadaan sebelum hubungan hukum perjanjian atau kata sepakat tercapai. (pra contráctuele verhouding).$^{63}$ Di beberapa Kitab UndangUndang Hukum negara lain, seperti Italia sudah dirumuskan kewajiban iktikad baik di dalam proses negosiasi dan penyusunan kontrak. Pasal 1337 Kode Sipil Italia menentukan:
"Trattative e responsabilita precontrattuale. - Le parti, nello svolgimento delle trattative e nella formazione den contratto, devono compartasi secondo bouna fede"

Di Belanda, doktrin iktikad baik dalam proses negosiasi dan penyusunan kontrak telah diakui keberadaannya melalui putusan Hoge Raad Belanda tanggal 15 November 1957 NJ 1958 No. $67 .{ }^{64}$ Putusan ini menyatakan bahwa para pihak yang berunding harus dilandasi iktikad baik; kepatutan, dan keadilan..$^{65}$ Sebagai konsekuensinya, pihak yang satu harus memperhatikan kepentingan hukum pihak lainnya dalam kontrak. ${ }^{66}$ Hoge Raad kemudian berhasil merumuskan atau menarik asas kecermatan dalam pembuatan kontrak (contractuele zorgvuldigheid, duty of care), yakni adanya kecermatan bagi pembeli untuk meneliti atau memeriksa (onderzoekplicht) fakta-fakta (facts) yang berkaitan subjek kontrak. ${ }^{67}$ Beberapa tahun kemudian Hoge Raad juga menerima kewajiban yang sama

${ }^{81}$ Sepadan dengan Pasal 1374 ayat (3) Kitab Undang-Undang Hukum Perdata Belanda (lama).

${ }^{82}$ Dengan ketentuan ini tidak berarti bahwa hukum Indonesia tidak mengenal sama sekali iktikad baik dalam pra kontrak. Pasal 251 Kitab Undang-Undang Hukum Dagang mengenal iktikad baik pra kontrak. Asas yang terkandung'di dalam pasal tersebut pada dasarnya merupakan asas uberima fides atau uberrima fidae (the principle of utmost good faith).

${ }^{83} \mathrm{Lihat} \mathrm{Gr}$ van der Burg. 1999. Buku tentang Perikatan dalam Teori dan Yurisprudensi Negeri Belanda Setelah Perang Dunia II. Saduran F. Tengker dan Wila Chandrawila Supriadi. Bandung: Mandar Maju. HIm 95 - 97. Lihat juga Ewoud H. Hondius (ed). 1991. Pracontractual Liability: Report to the XIIIth Congress International Academy of Comparative Law Montreal, Canada, 18 - 24 August, 1990. Deventer: Kluwer. HIm. 63.

${ }^{84}$ P. L. Wery. Op.Cit. HIm. 15.

${ }^{65}$ Arthur S. Hartkamp dan Marianne M.M. Tillema. Op.Cit. HIm. 71.

${ }^{66}$ Ewoud Hondius (ed). Op.Cit. HIm. 226.

${ }^{67}$ Ibid. 
bagi penjual untuk memberitahukan (mededelingsplicht) fakta meterial (material facts) bagi penjual dalam proses negosiasi kontrak ${ }^{68}$ Sebagai akibat dari pandangan tersebut, maka setiap orang wajib memiliki contractuele zorgvuldigheid (kecermatan dalam pembuatan perjanjian) dan contractuele rechtwaardigheid (kemulian dalam perjanjian). Dengan demikian, sejak saat diadakannya perjanjian harus sudah ada maatschapelijke zorgvuldigheid atau kepatutan, ketelitian, dan kehatian-hatian dalam pergaulan kehidupan hukum masyarakat. Dengan demikian, negosiasi kontrak atau proses penyusunan kontrak harus dilandasi iktikad baik, tidak dengan iktikad buruk (bad faith). ${ }^{69}$

Sesungguhnya, pandangan Hoge Raad tersebut di atas dipengaruhi oleh dua sarjana hukum Eropa terkenal. Pertama, Rudolf von Jhering yang mengintrodusikan konsep culpa in contrahendo pada tahun 1861. Kedua, Raymon Saleilles yang pada tahun 1907 mengembangkan ketentuan asas iktikad baik dan fair dealing dalam hubungan pra kontrak. ${ }^{70}$

Penerapan iktikad baik di dalam hubungan pra kontrak masih menimbulkan berbagai permasalahan. Permasalahan tersebut berkaitan dengan apakah hubungan pra kontrak termasuk hubungan hukum kontrak ataukah hubungan hukum lainnya? Norma apakah yang mengatur hubungan pra kontrak tersebut? Apakah hubungan tersebut merupakan perbuatan melawan hukum (tort) dan berkaitan dengan asas kecermatan pithak yang satu terhadap pihak lainnya (duty of care), dan apakah prinsip iktikad baik yang diderivasi dari hukum kontrak?

Di dalam hukum Belgia, Perancis, dan Venezuela, hubungan pra kontrak umumnya diletakkan pada perbuatan melawan hukum. $\mathrm{Di}$ beberapa hukum negara lain tidak terlalu dibedakan antara kontrak dan perbuatan melawan hukum. Di Cheko, Slovakia, dan Belanda, hubungan hukum di dalam pra kontrak tidak diperhatikan apakah hubungan tersebut kewajiban kontraktual atau bukan. $\mathrm{Hal}$ yang sama juga terjadi di Jepang. Di dalam yurisprudensi Jepang dijumpai bahwa kadang hubungan pra kontrak didasarkan pada perbuatan melawan hukum, dan kadangkadang pula didasarkan kontrak pendahuluan atau quasi kontrak. ${ }^{71}$ Di beberapa negara lain seperti Italia dan Swiss, hubungan hukum pra kontrak yang demikian masih dianggap membingungkan, namun demikian, Mahkamah Agung Swiss lebih mendukung teori perbuatan melawan hukum daripada teori kontrak. ${ }^{22}$

Di beberapa negara hukum sipil lainnya, upaya hukum terhadap adanya unfair dealing

${ }^{68} /$ bid.

${ }^{69}$ Arthur Hartkamp dan Marianne M.M. Tillema. Loc.Cit. Walaupun yurisprudensi Belanda telah menerima asas iktikad baik dalam proses negosiasi dan penyusunan kontrak, tetapi asas tersebut belum diadopsi Kitab Undang-Undang Hukum Perdata Belanda (Baru). Pembentuk undang-undang lebih cenderung menyerahkannya kepada pengadilan untuk mengembangkan asas tersebut. Lihat Ewoud Hondius (ed). Op.Cit. HIm. 10 dan 227.

${ }^{70} \mathrm{lbid}$. Ewoud Hondius (ed). HIm. 225.

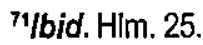

?2/bid. 
dalam hubungan pra konrak lebih spesifik lagi, yakni penyalahgunaan hak (abuse rights). Teori ini antara lain diikuti Mahkamah Agung Puerto Rico dalam perkara Producciones Tommy Munis Inc v COPAN. Mahkamah Agung menyatakan: ${ }^{73}$

"it could be argued, however, that unjustified breach of agreements is nothing more than exercises of right, inasmuch as the parties are completely free to bind themselves or to stop the negotiation..."

Di dalam kontrak, iktikad baik memiliki dua fungsi. Fungsi pertama adalah fungsi menambah (aanvullende werking van de goede trouw) ${ }^{74}$ Dengan fungsi ini hakim dapat menambah isi perjanjian dan menambah kata-kata peraturan perundang-undangan yang berkaitan dengan perjanjian itu. ${ }^{75}$ Fungsi kedua adalah fungsi membatasi dan meniadakan (beperkende en derogerende werking van de goede trouw). ${ }^{76}$ Dengan fungsi ini hakim dapat mengesampingkan isi perjanjian atau peraturan perundang- undangan yang berkaitan dengan perjanjian jika terjadi perubahan keadaan. ${ }^{77}$ Perubahan keadaan itu sedemikian rupa mengakibatkan pelaksanaan apa yang terdapat di dalam suatu perjanjian atau peraturan perundangundangan menjadi tidak adil lagi. ${ }^{78}$

Tidak semua ahli hukum dan pengadilan menyetujui fungsi kedua iktikad baik di atas, karena hal tersebut banyak hal bersinggungan dengan keadaan memaksa (overmacht). Jika tidak ada keadaan memaksa debitur tidak dapat dibebaskan dari kewajiban kontraktualnya. ${ }^{79}$ Dalam perkembangannya, di Belanda sejak tahun 1967 fungsi iktikad baik yang kedua telah diterima pengadilan, namun fungsi tersebut hanya boleh dilaksanakan jika ada alasan yang penting (alleen in sprekende gevallen). Baik Hoge Raad maupun Kitab Undang Hukum Perdata Belanda (Baru) ${ }^{80}$ mengijinkan pembatasan perjanjian hanya dalam kasus-kasus di mana pelaksanaan perjanjian tidak diterima karena tidak adii. ${ }^{81}$ Selain kedua fungsi di atas, iktikad baik juga memiliki peranan penting dalam penafsiran

${ }^{73}$ ibid. HIm. 12.

${ }^{74}$ P.L. Wery. Op.Cit. Him. 18

${ }^{75} /$ bid.

${ }^{76}$ lbid.

${ }^{77}$ lbid.

${ }^{78} / \mathrm{bid}$. Di dalam hukum kontrak common law, ajaran perubahan keadaan ini disebut doktrin frustration on contract. Lihat juga Walter Woon. 1995. Basic Business Law in Singapore. Singapore: Prentice Hall. HIm. 52 - 53. Lihat juga Ewan MacKendrick. 1990. Contract Law. London: Macmillan. HIm 184 - 85. Doktrin ini juga dikaitkan dengan iktikad baik dan kepatutan. Lihat Purwahid Patrik. Asas ...Op.Cit. HIm. 19-20.

${ }^{79}$ P.L. Wery. Op.Cit. Him. 11. (Baru).

${ }^{80}$ Lihat Pasal 6: 2 ayat (2) dan Pasal 6; 248 ayat (2) Kitab Undang-Undang Hukum Perdata Belanda B'P.L. Wery. Op.Cit. HIm. 13. 
kontrak. $^{82}$ Kontrak harus ditafsirkan sesuai dengan iktikad baik. ${ }^{33}$

Atas dasar iktikad baik ini, maka kewajibankewajiban kontraktual dibatasi, bahkan dapat ditiadakán seluruhnya atas dasar iktikad baik. ${ }^{84}$ Jadi, ajaran iktikad baik secara eksplisit memberikan kewenangan kepada pengadilan atas dasar kepatutan (faimess) untuk merevisi atau bahkan meniadakan seluruh isi perjanjian. ${ }^{85}$

Dengan demikian, jelaslah bahwa dengan perluasan makna dan ruang iktikad baik tersebut, mengakibatkan kebebasan para pihak untuk menentukan iși dan bentuk kontrak makin dibatasi. ${ }^{86}$

Di dalam perkara $\mathrm{Ny}$ Lie Lian Joun melawan Arthur Tutuarima87, Pengadilan Tinggi Bandung menyatakan, bahwa perjanjian harus dilaksanakan dengan iktikad baik. Oleh karenanya, perjanjian haruslah suatu perjanjian yang patut dan adil. Menurut Pengadilan Tinggi Bandung, apabila di dalam perjanjian itu tidak terdapat kepatutan dan keadilan, hakim dapat merubah perjanjian tersebut. Perubahan tersebut adalah merubah isi perjanjian. Perjanjian tidak hanya ditentukan oleh rangkaian kata-kata yang disusun para pihak, tetapi juga ditentukan kepatutan dan keadilan. Dalam perkara ini, hakim tinggi tersebut tidak memberikan tafsiran makna iktikad baik tersebut, kecuali menyebutkan iktikad baik harus didasarkan pada kepatutan dan keadilan. Di dalam perkara S.T. Silalahi melawan Suryono dan kawankawan, ${ }^{88} \quad$ Mahkamah Agung mengimplementasikan iktikad baik dengan cara membagi dua risiko antara debitur dan kreditur terhadap adanya perubahan nilai mata uang. Mahkamah Agung berpandangan bahwa risiko perubahan atas nilai mata uang dibebankan kepada keduabelah pihak menurut imbangan yang sama dengan menggunakan harga emas sebagai standar atau patokannya. ${ }^{89}$

Tidak semua sistem hukum di dunia ini menerima konsep atau doktrin iktikad baik. Pada dasarnya doktrin iktikad berasal dari hukum kontrak sistem hukum sipil yang berakar pada hukum romawi..$^{90}$ Sistem common law, secara tradisional tidak mengenal

${ }^{82}$ Martijn Hassenlink. Op.Cit. HIm. 291.

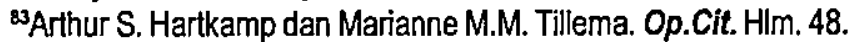

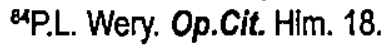

${ }^{85}$ Charles Fried. 1981. Contract as Promises, a Theory of Contractual Obligation. Cambridge: Harvard University Press. HIm. 74.

${ }^{88}$ Purwahid Patrik. Op.Cit. Hilm. 8.

871972. Yurisprudensi Indonesia. Jakarta: Mahkamah Agung. HIm. 137-163

${ }^{89}$ Setiawan. Menurunnya ...Op.Cit. Hlm. 3.

${ }^{99}$ Pandangan ini mengikuti yurisprudensi sebelumnya, yakni Putusan Mahkamah Agung Tanggal 27 April 1955 Nomor 92.Ksip/1952 dan Putusan Mahkamah Agung Tanggal 11 Mei 1955 Nomor 26 K/Sip/1955. Lihat Subekti. 1984. Hukum Perjanjian. Jakarta: Intermasa. HIm. 43.

${ }^{90}$ E.Allan Farnsworth. "Good Faith in Contract Performance." Jack Beatson dan Daniel Friedman (eds). Op.Cit. HIm. 154. 
doktrin iktikad baik dalam kontrak...1 Hukum Negara dengan sistem common lawyang telah menerima doktrin iktikad baik sistem hukum kontraknya adalah Amerika Serikat. Doktrin tersebut terefleksi dalam: The Uniform Commercial Code (UCC). The American Law Institute's Restatement (2nd) Contract, dan United Nations Convention on Contracts for the International Sale of Goods. Ketiganya menerima doktrin iktikad baik dalam pelaksanaan kontrak

Tidak semua negara yang menganut sistem common law mau menerima doktrin iktikad baik. Hukum Inggris yang secara tradisional tidak mengenal iktikad baik dalam kontrak cenderung menolaknya, bahkan selama tahun 1960-an ada konsensus di antara hakim-hakim di Inggris untuk tidak menerima doktrin tersebut, dan mempertahankan sistem hukum yang dimiliki Inggris sendiri. ${ }^{22}$ Penolakan tersebut terjadi pada kalangan sarjana hukum Inggris, seperti Roy Goode yang menyatakan sulit untuk mengadopsi konsep umum iktikad baik tersebut, bahkan ia menyatakan, "we do not know quite what good faith means ? ${ }^{\text {n93 }}$
Penolakan penerapam doktrin iktikad baik di Australia juga mendapat tantangan dari beberapa sarjana hukum Australia, seperti H.K. Lucke. Dia menyatakan bahwa tidak masuk akal untuk mengharapkan bahwa doktrin iktikad baik memberikan pengaruh yang signifikan dan menguntungkan hukum perdata Australia. ${ }^{94}$ Dia mendukung pendapat Paul Pinn yang menyatakan bahwa keadilan bukan merupakan milik ekskusif doktrin iktikad baik. ${ }^{95}$ Walaupun ada tantangan dari kalangan akademisi hukum, dalam kenyataannya dewasa ini, doktrin tersebut telah diserap pula oleh case law Australia. ${ }^{96}$

Dalam menghadapi ketidakpantasan dan ketidakadilan baik dalam negosiasi dan penyusunan kontrak, di negara-negara dengan sistem common law tidak dianut perluasan iktikad baik ke dalam hubungan pra kontrak. Mereka mendasarkan kepada doktrin undue influence ${ }^{97}$ dan doktrin unconscionability.

Di negara-negara common law ajaran penyalahgunaan keadaan telah dikenal di dalam doktrin equtiy. ${ }^{98}$ Di dalam kasus Lloyds Bank Ltd v Bundy (1075) QB, Lord Denning MR mencoba menunjukkan bahwa

${ }^{2}$ 'Martijn Hasenlink. Op.Cit. HIm. 287.

92 Jack Beatson dan Daniel Friedman. "Introduction: From "Clasical" to Modem Contract Law." Jack Beatson dan Daniel Friedmann (eds). Op.Cit. HIm. 5.

${ }^{93}$ Jack Beatson dan Daniel.Friedmann. Op.Cit. HIm. 157.

sulbid.

${ }^{95} /$ bid.

${ }^{96}$ R.A. Ladbury dan I.M. Paterson. "Influence of Continental European Law on Australian Commercial Law." International Business Lawyer. Januari1997. $\mathrm{Hlm}$. 32.

${ }^{97}$ Setiawan. "Kontrak Standär dalam Teoridan Praktek." Varia Peradilan. Tahun IX No. 103 II. April 1994. Hilm. 156.

${ }^{98}$ Equity adalah doktrin yang membolehkan hakim untuk membuat suatu putusan yang didasarkan pada asas kapatutan (faimess), persamaan (equality), hak moral (moral rights), dan hukum alam (natural law). Lihat Henry R. Cheeseman. 2000Contemporary Business Law. New Jersey: Prentice Hall. HIm. 195. 
penyalahgunaan keadaan bukanlah doktrin yang benar-benar berdiri sendiri. Doktrin ini sebenarnya merupakan perluasan dari power of equity bagi pengadilan untuk mengintervensi suatu perjanjian yang $\mathrm{di}$ dalamnya terdapat suatu penyalahgunaan posisi yang tidak seimbang di antara para pihak. ${ }^{99}$ Menurut Robert Upex, doktrin penyalahgunaan keadaan ini merupakan perluasan dari doktrin equity yang disebut equitable fraud. ${ }^{100}$ Penyalahgunaan keadaan di dalam sistem common law merupakan doktrin yang menentukan pembatalan perjanjian yang dibuat berdasar tekanan yang tidak patut, tetapi tidak termasuk dalam kategori paksaan (duress). ${ }^{101}$ Penyalahgunaan keadaan terjadi manakala seseorang di dalam suatu perjanjian dipengaruhi oleh suatu hal yang menghalanginya untuk melakukan penilaian (judgment) yang bebas dari pihak lainnya, sehingga ia tidak dapat mengambil putusan yang independen. ${ }^{102}$ Penekanan tersebut dapat dilakukan karena salah satu pihak memiliki kedudukan khusus (misalnya kedudukan yang lebih dominan atau memiliki hubungan yang bersifat fiduciary dan confidence). ${ }^{103}$ Pihak yang memiliki kedudukan khusus itu mengambil keuntungan secara tidak pantas dari pihak lainnya yang lebih lemah. ${ }^{104} \mathrm{Hal}$ tersebut dilakukan tanpa adanya paksaan atau tipuan. ${ }^{105}$ Dengan perkataan lain, Van Dunne menyatakan bahwa penyalahgunaan keadaan tersebut dapat terjadi karena keunggulan ekonomis maupun kejiwaan. ${ }^{106}$ Jadi, di sini terjadi

${ }^{99}$ T. Antony Downes. 1997. Contract. London: Blackstone Press Limited. Hlm. 180.

${ }^{100}$ Robert Upex. 1991. Davies on Contract. London: Sweet \& Maxwell. HIm. 118.

${ }^{101}$ T. Antony Downes. Op.Cit. HIm 184. Lihat juga A.G. Guest. Op.Cit. HIm 273. Lihat juga Roberth Upex. Op.Cit. HIm. 113. Lihatjuga P.S. Atiyah. 1981. An Introduction to the Law of Contract. Oxford: Clarendon Press. HIm. 231. Lihat juga Stephen Graw. 1994. An Introduction to the Law of Contract. Sydney: The Law Book Co. Ltd. HIm. 252.

${ }^{102}$ Catherine Tay Swee Kian dan Tang See Chim. 1987. Contract Law. Singapore: Times Book International. HIm 80. Lihat pula PauI Latimer. 1997. Australian Business Law. Sydney: CCH Australia Limited. HIm. $327-328$.

${ }^{103}$ A.G. Guest. Loc.Cit. Lihat juga Daniel V. Davidson. et.al. 1987. Comprehensive Business Law. Boston: Kent Publishing Co. HIm. 266.

${ }^{104}$ Robert W. Clark. 1987. Inequality of Bargaining Power, Judicial Intervention in Improvident and Unconsionable Bargain. Toronto: Carswell. Hlm. 95. Lihat juga Michael H. Whincup. 1990. Contract Law and Practice, The English System and Continental Comparisions. Deventer: Kluwer. HIm. 213.

${ }^{105}$ S.M. Waddams. 1984. The Law of Contract. Toronto: Canada Law Book inc. HIm. 385.

${ }^{106}$ J.M. van Dunne dan Grvan der Burght. "Penyalahgunaan Keadaan." Materi Kursus Hukum Perikatan Bagian III. terjemahan Sudikno Mertokusumo. Kerjasama antara Dewan Kerjasama llmu Hukum Belanda dan Proyek Hukum Perdata Indonesia, Semarang 22 Agustus - September 1988, him 16-27. Dengan bahasa yang lain Henry R. Cheseeman menyatakan bahwa penyalahgunaan keadaan terjadi karena adanya kelemahan satu pihak, yakni kelemahan mental, emosi, fisik. Lihat Henry Cheseeman. contemporary ... Op.Cit. HIm. 251. 
ketidakseimbangan hubungan di dalam proses terjadinya suatu kontrak. ${ }^{107}$

Apabila di dalam suatu perjanjian terdapat unsur-unsur penyalahgunaan keadaan, maka pengadilan dapat membatalkan perjanjian tersebut. ${ }^{108}$ Berkembangnya ajaran penyalahgunaan keadaan baik di dalam sistem hukum kontinental (seperti hukum Belanda) dan sistem hukum common law menjadi pembatas baru bagi kebebasan berkontrak.

Doktrin penyalahgunaan keadaan di Belanda mulai diterima adanya putusan Hoge Raad Belanda yang dikenal dengan Bovag Arrest II. ${ }^{109}$ Di Negeri Belanda dewasa ini, doktrin dan yurisprudensi tersebut telah diangkat ke dalam Pasal 3: 44 Kitab UndangUndang Hukum Perdata. Pasal tersebut menyebutkan: Een rechtshandeling is vernietigbaar, wanneer zij door bedreiging, door bedrog of door misbruik van omstandigheden is tot gekomen. Dalam. perumusan pasal tersebut, Meijer sebagai pelopor penyusan Kitab Undang-Undang Hukum Perdata tersebut, mendapat insipirasi dari doktrin undue influence dalam hukum Inggris. ${ }^{10}$

Ajaran penyalahgunaan keadaan $\mathrm{di}$ Indonesia relatif baru. Berlainan dengan di Negeri Belanda, doktrin penyalahgunaan keadaan belum dijadikan sebagai hukum positif. Penerapan doktrin penyalahgunaan keadaan dalam sistem hukum sipil seperti Indonesia masih menimbulkan perdebatan. Di dalam sistem hukum Indonesia dan kebanyakan hukum sipil pada umumnya telah dikenal adanya doktrin iktikad baik yang mencakup iktikad baik dalam proses negosiasi dan penyusunan kontrak serta pelaksanaan kontrak. Selain itu, seringkali dijumpai adanya kesalahan dalam memahami makna penyalahgunaan keadaan, bahkin ada yang menyamakan penyalahgunaan keadaan dengan

Lihat juga A.M. Bloembergen, et.al (eds). 1995. Rechtshandeling dan Overeenkomst. Deventer: Kluwer. HIm. 205 - 206.

${ }^{107}$ Doktrin penyalahgunaan keadaan ini tidak mencari dasar pembenarannya pada doktrin kausa hukum yang tidak halal, melainkan pada cacat kehendak (wilsgebrek). Lihat Setiawan. "Menurunnya Supremasi Asas Kebebasan Berkontrak." Newsletter. No. 15/IV/Desèmber/1993. Apabila ketidakseimbangan tersebut antara prestasi dan kontraprestasi, lebih tepat dikaitkan dengan doktrin unconscionability. Lihat Gary A, Moore. et.ai. 1987. The Legal Environment of Business: A Contextual Approach. Cincinnati: South Western Publishing Co. HIm. 239 - 240.

${ }^{108}$ T. Antony Downes. Op.Cit. Him 184. Perhatikan pula Buku 3 Pasal 44 ayat (1) Burgerlijk Wetboek (Baru) Belanda. Lihat juga John D. Calamari dan Joseph M. Perillo. Op.Cit. HIm. 277.

${ }^{109}$ Setiawan, op.cit. HIm. 81. Lihat juga Henry P. Penggabean. 1992. Penyalahgunaan Keadaan (Misbruik van Omstandigheiden) sebagai Alasan (Baru) Pembatatalan Perjanjian. Yogyakarta: Liberty. HIm. 44. Lihat juga J.M. van Dunne dan Gr van den Burght. "Penyalagunaan Keadaan." Materi Kursus Hukum Perikatan Bagian III Terjemahan Sudikno Mertokusumo. Kejasama antara Dewan Kerjasama Hukum Belanda dan Proyek Hukum Perdata Indonesia, Semarang 22 Agustus - 3.September 1988, HIm. 4.

${ }^{110}$ Lihat J.M. van Dunne. 1993. Verbintenissenrecht, Deel 1, Contractenrecht, 1e gedelte. Deventer: Kluwer. Hlm. 381. 
unconscionability. ${ }^{111}$ Keduanya memiliki kesamaan pada adanya ketidakseimbangan posisi tawar para pihak, tetapi di antara keduanya ada perbedaan. Dalam kasus Commercial Bank of Australia v Amadio (1983) 151 CLR 447 Deane $\mathrm{J}$ menyatakan bahwa penyalahgunaan keadaan merupakan akibat dari adanya ketidakseimbangan posisi tawar itu terhadap pemberian kata sepakat (consent atau assent) dari pihak yang lemah (weaker party) atau yang dipengaruhi. Unconscionability dipandang dari perilaku yang posisi tawarnya lebih kuat untuk memaksakan atau memanfaatkan transaksi terhadap yang lebih lemah posisi tawarnya dalam 'keadaan tertentu yang tidak sesuai dengan keadilan (equity) dan kepatutan (good conscience). ${ }^{112}$

Ketidakjelasan tersebut berimbas pula di dalam praktik perádilan. Misalnya dalam kasus Sri Setyaningsih versus $N y$ Boesono dan $R$ Boesono, Hakim Agung bersikap bahwa'bunga yang ditetapkan kreditur sebesar $10 \%$ sebulan adalah tidak sesuai dengan kepatutan dan keadilan. Bunga tersebut terlalu tinggi. Atas dasar iktikad baik, hakim agung mengurangi bunga tersebut menjadi $1 \%$ per bulan. Walaupun secara tegas dikatakan bahwa kontrak tersebut adalah bertentangan kepatutan dan keadilan yang merupakan inti atau isi iktikad baik, tetapi di dalam catatan yang diberikan Z. Asikin Kusumah Atmadja, menyatakan bahwa iktikad baik tidak dapat diterapkan di sini. Di sini terjadi penyalahgunaan keadaan. Penyalahgunaan tersebut dimungkinkan karena adanya ketidakseimbangan dan ketidakserasian kedudukan para pihak. ${ }^{113}$ Hakim menurut $Z$. Asikin 'Kusumah Atmadja'114 tidak menggolongkan penyalahgunaan keadaan itu ke dalam kategori ajaran yang dikuasai iktikad baik, karena di dalam iktikad baik yang dipersoalkan adalah cara untuk memperoleh hak atau wewenang. Dalam cacat kehendak yang dipersoalkan adalah bagaimana sejarahnya sampai diperoleh hak atau kewenangan tersebut. Tegasnya persoalan itu terletak dalam sejarah terjadinya perolehan hak (het verleden) dan tidak seperti halnya iktikad baik, yakni bagaimana cara pada waktu melakukan perbuatan untuk memperoleh hak atau wewenang.

Berdasarkan penjelasan di atas, terlihat adanya kelemahan atau kekurangan dalam pengaturan substansi hukum kontrak, khususnya yang berkaitan dengan pengaturan iktikad baik dan penyalahgunaan keadaan. Undang-unidang itu tidak sempurna. Tidak mungkin undang-undang mengatur segala kehidupan manusia secara tuntas. Hukum bukanlah suatu hal yang statis. Hukum adalah

"Ir Sambir Melati Hatta, dengan mengutip pendapatZ. Asikin Kusumah Atmadja mensepadankan misbruik omstandigheiden (Belanda) dengan doktrin unconscionability (common Law). Lihat Sri Melati Gambir Hatta. 1999. Beli Sewa sebagai Perjanjian Tak Bernama: Pandangan Masyarakat dan Sikap Mahkamah Agung Indonesia. Bandung: Alumni. HIm. 139.

112 Ibid.

${ }^{113}$ Lihat Retnowulan Sutantio. "Perjanjian menurut Hukum Indonesia." Varia Peradilan. Tahun V No 56. Mei 1990. HIm. 131.

${ }^{114}$ Z. Asikin Kusumah Atmadja. Op Cit. Hlm. 368. 
bagian dari masyarakat. Oleh karena itu, hukum tumbuh dan berkembang bersama masyarakat itu sendiri ${ }^{115}$ Pendapat yang ekstrim menyatakan bahwa begitu suatu aturan dikodifikasikan, pada saat yang sama ia akan ketinggalan zaman. ${ }^{16}$ Hukum berkembang di luar kodifikasi. Adakalanya undang-undang itu tidak lengkap dan adakalanya pula tidak jelas, meskipun undang-undang tidak lengkap atau tidak jelas, undang-undang harus tetap dilaksanakan. ${ }^{11 ?}$ Kekosongan dan ketidakjelasan hukum tersebut harus diisi oleh pengadilan. Dalam keadaan demikian, yurisprudensi memiliki arti yang sangat penting dalam penegakan hukum.

Dalam menghadapi kasus tertentu atau sengketa yang mengandung keadaan tertentu (particular circumstances) maupun particular reason yang belum diatur dalam undangundang, diperlukan cara penyelesaian yang khusus pula. Dapat pula kasus tersebut telah diatur di dalam peraturan perundangundangan, tetapi substansinya terlalu umum, abstrak, dan bertentangan dengan kepentingan umum atau rumusan tidak sesuai dengan kepatutan. ${ }^{118}$ Dalam keadaan demikian, hakim berfungsi sebagai judges as laws maker..$^{119}$ Bagaimana hakim mengimplementasikan hukum di pengadilan bergantung pada interpretasi hakim. ${ }^{120}$ Hakim juga berkewajiban pula untuk menginterpretasikan kemauan pembentuk undang-undang dalam perkara tertentu. ${ }^{121}$

Hakim, melalui interpretasinya memiliki peran penting untuk mengurangi kelemahan dan kekurangan itu. Hakim memiliki kewenangan judges as laws maker. Dengan kewenangan tersebut menjadikan hakim sebagai orang yang dapat menjadikan undang-undang yang dimaksud tetap aktual dan efektif. ${ }^{122}$ Dengan demikian, putusan pengadilan menjadi hukum yang sesungguhnya berlaku (law in action) dalam peristiwa konkreto yang berhubungan dengan kasus tertentu (particular cases). ${ }^{123}$

Dari putusan pengadilan ini akan tergambar pula bagaimana sikap hakim dalam menilai iktikad baik dalam kontrak. Perkembangan konsep iktikad baik yang telah disebutkan di atas umumnya didasarkan kepada doktrin baik yang berasal dari pendapat sarjana maupun putusan pengadilan. Dari putusan pengadilan ini pula akan tergambar bagaimana sikap pengadilan untuk menerapkan doktrin tersebut atau tidak menerapkan doktrin tersebut atau bahkan

${ }^{115}$ Setiawan. "Publikasi Putusan Hakim." Varia Peradilan. Tahun VIII No. 95 (Agustus 1993).

116 /bid.

${ }^{117}$ M.Yahya Harahap. 1997. Beberapa Tinjauan tentang Permasalahan Hukum, Buku Kesatu, Bandung: Citra Aditya Bakti. Hlm. 184:

${ }^{118} \mathrm{Ibid}$.

${ }^{119}$ Arthur Lewis. 1998. Introduction to Business Law. Wirral: Tudor Business Publishing Ltd. HIm. 9.

$120 \mathrm{lbid}$. HIm. 11.

$121 \mathrm{Jbid} . \mathrm{HIm} .188$.

${ }^{122} \mathrm{Ibid}$. HIm. 185.

${ }^{123}$ Z.Asikin Kusumah Atmadja. Op.Cit. HIm. 341. 
justeru menimbulkan doktrin baru. Dari putusan pengadilan ini akan terlihat pula bagaimana peranan hakim. dalam menafsirkan suatu peraturan perundangundangan yang kurang jelas atau bahkan dianggap tidak adil.

Dalam kasus Indonesia, sikap pengadilan ini penting artinya sehubungan dengan tesis yang dikemukakan Z. Asikin Kusumah Atmadja. Dia berpendapat bahwa kebebasan berkontrak harus disertai dengan keadilan dalam kontrak yang bersama-sama merupakan suatu pengertian kecermatan berkontrak. Kecermatan berkontrak tersebut diiringi pula dengan kecermatan masyarakat. ${ }^{124}$ Jalan berpikir yang demikian harus menjadi dasar utama atau pegangan dalam menghadapi suatu kontrak yang mengandung unsur penyalahgunaan keadaan. Dalam kenyataannya, hal tersebut belum sepenuhnya disadari para hakim Indonesia. ${ }^{125}$

Sistem peradilan Indonesia tidak menganut sistem precedent sebagaimana peradilan di negara-negara dengan sistem common law, maka hakim tidak berkewajiban mengikuti putusan pengadilan sebelumnya. Sistem ini mengikuti sistem peradilan di negara hukum sipil, seperti Perancis. Sistem hukum Perancis tidak mengakui yurisprudensi sebagai sumber hukum. ${ }^{126}$ Dengan demikian tidak ada kewajiban bagi seorang hakim untuk kasus yang sama mengikuti putusan hakim sebelumnya. ${ }^{127}$ Di dalam perkembangannya dewasa ini, praktik menunjukkan bahwa banyak hakim di Perancis daiam memutus suatu perkara mengikuti putusan hakim sebelumnya. ${ }^{128}$ Jika sistem peradilan indonesia masih mengikuti pola lama sistem peradilan hukum sipil, maka terdapat kemungkinan adanya perbedaan sikap di antara para pihak dalam menilai atau mensikapi konsep iktikad baik. Ini terbukti dari putusan Mahkamah Agung terkadang lebih mengkedepankan asas pacta sunt servanda, tetapi ada pula yang lebih mengkedepankan asas iktikad baik daripada asas pacta sunt servanda.

\section{Kaitan Iktikad Baik dengan Penemuan Hukum}

Dalam menilai iktikad baik, hakim harus memperhatikan kepatutan dan keadilan. Setiap kontrak harus didasarkan pretium iustum yang mengacu kepada reason dan equity yang mensyaratkan adanya keseimbangan antara kerugian dan keuntungan bagi keduabelah pihak dalam kontrak (just price). ${ }^{129}$ hal tersebut sejalan

\section{${ }^{124}$ /bid. HIm. 342.}

${ }^{125}$ Donald Haris dan Dennis Tallon (eds). Op.Cit. HIm. 10.

${ }^{126}$ Perhatikan Pasal 4 dan 5 Kode Sipil Perancis. Lihat Benjamin Watt. "Why French Law Reject Judicial Precedent." International Business Lawyer. (January 1997). Hlm. 19.

${ }^{127}$ Jacques Sales. "Why Judicial Precedent is a Source of Law in France." International Business Lawyer, (January 1997). HIm. 21.

${ }^{128}$ Harold J Berman. Loc.Cit.

${ }^{129}$ Sudikno Mertokusumo. Op.Cit.Hilm 71. 
dengan tujuan hukum sendiri, yakni merealisasikan keadilan. ${ }^{130}$ Isi hukum, termasuk isi kontrak harus memuat nilai-nilai keadilan.

Di dalam konteks hukum kontrak, hakim memiliki kewenangan untuk mencegah terjadinya pelanggaran rasa keadilan. ${ }^{131}$ Dengan kewenangannya, hakim berhak menghapuskan sama sekali suatu kewajiban kontraktual dari suatu kontrak yang mengandung ketidakadilan. ${ }^{132}$ Mengikuti yurisprudensi di Belanda, maka kepatutan dañ keadilan tersebut adalah kepatutan dan keadilan yang berkembang dalam masyarakat.

Hakim dalam melaksanakan fungsi dan kewenangan kehakiman diberikan otonomi kebebasan. Otonomi kebebasan tersebut mencakup: ${ }^{133}$

1. Menafsirkan peraturan perundangundangan;

2. Mencari dan menemukan asas-asas dan dasar-dasar hukum;

3. Mencipta hukum baru apabila menghadapi kekosongan peraturan perundang-undangan;

4. Dibenarkan pula melakukan contra logem apabila ketentuan peraturan perundang- undangan bertentangan dengan kepentingan umum; dan

5. Memiliki otonomi yang bebas untuk mengikuti yurisprudensi.

Dengan fungsi dan kewenangan yang demikian itu, hakim dibenarkan bertindak menciptakan hukum. Kewenangan tersebut dilakukan melalui mekanisme judge made law yang terbatas pada kasus tertentu. Dalam hal ini hakim melakukan penemuan hukum, dalam arti hakim melakukan proses pembentukan hukum. Ini merupakan proses kongkritisasi dan invidualisasi peraturan hukum yang bersifat umum dengan mengingat peristiwa kongkrit. ${ }^{134}$

Dengan kewenangan yang dimiliki hakim tersebut, penemuan hukum yang dilakukan tidak sekedar menginterpretasi undangundang atau hanya melaksanakan undangundang saja, tetapi juga penemuan hukum karena hakim bukan hanya sebagai corong undang-undang (la bouche du droit). ${ }^{135}$ Dengan demikian proses pengadilan bukanlah suatu silogisme. Undang-undang merupakan premis mayor, peristiwa kongkrit adalah premis minor, sedangkan putusan hakim adalah konklusi atau kesimpulannya. ${ }^{136}$

\footnotetext{
${ }^{130}$ Subekti. Perjanjian....Op.Cit. HIm 43.

131 Ibid.
}

${ }^{132}$ Retnowulan Sutantio. Op.Cit. HIm. 144.

${ }^{133}$ Sudikno Mertokusumo dan A. Pitlo. Op.Cit. HIm. 4.

${ }^{134}$ Setiawan. "Pengaruh Yurisprudensi terhadap Peraturan Perundang-undangan." Varia Peradilan. Tahun VI No. 65 (Februari 1991). HIm. 140.

${ }^{135}$ Pandangan yang menekankan silogisme dalam pengambilan putusan pengadilan merupakan pandangan yang typis logistis. Lihat John Henry Merryman. 1969. The Civil Law Tradition: An Introduction to the Legal System of Western Europe and Latin America. Stanford: Stanford University Press. HIm $37-38$. Wiarda menyebutnya sebagai penemuan heteronom, karena hakim tidak mandiri karena harus tunduk kepada undang-undang. Lihat Sudikno Mertokusumo dan A. Pitlo. Op.Cit. HIm 7.

${ }^{136} \mathrm{Ibid}$. HIm 29 
Dengan kewenangan yang dimiliki hakim itu, hakim dapat melakukan penemuan hukum bebas. Undang-undang memang harus dihormati, tetapi undang-undang selalu ketinggalan zaman, sehingga hakim tidak harus secara mutlak mematuhinya. Hakim dapat melihat undang-undang sebagai alat atau sarana untuk membantu menemukan hukum. Di sini hakim tidak semata-mata berfungsi menafsirkan undang, tetapi juga berfungsi sebagai pencipta hukum. ${ }^{137}$ Dalam keadaan demikian, hakim harus selalu mengikuti perkembangan zaman dan akan memperharui aturan hukum yang sudah usang. Sehubungan dengan hal ini Cardozo menyatakan:

"My duty as judge may be objectify in law, not my own aspiration and conviction and philosophies, but the aspiration and conviction and philosophies of the men and women on my time. Hardly shall I do this well if my own sympathies and beliefs and passionate devotions are with a time that is past". ${ }^{38}$

Seorang hakim yang baik adalah penterjemah dari rasa keadilan bangsanya. Seorang hakim harus dapat mengkuti dan menghayati terjadinya perubahan nilai dalam hubungan kemasyarakatan. Melalui intrepretasi yang baik, hukum akan tetap hidup dari masa ke masa dan memberikan rasa keadilan bagi mereka yang mendambakannya. ${ }^{139}$ Sehubungan dengan hal tersebut Pitlo mengumpamakan naskah undang-undang sebagai partitur sebuah lagu. la merupakan huruf-huruf yang mati. Lagu itu akan hidup apabila dimainkan. Lagu itu akan semakin baik terdengar apabila dimainkan oleh seorang pemusik ulung. Pemusik itulah yang memberi isi dan jiwa lagu tersebut. Seorang hakim yang baik dalam menafsirkan undang-undang bagaikan seorang pemusik yang dapat memberikan isi dan jiwa undangundang tersebut. Hukum yang hidup adalah hukum yang mengendap dalam putusan hakim.

\section{Simpulan}

Iktikad baik merupakan asas penting di dalam hukum kontrak yang memberikan kewenangan kepada hakim untuk melakukan intervensi terhadap suatu kewajiban Kontraktual. Hakim dapat mengunakan tiga fungsi iktikad baik, yakni sebagai instrumen untuk melengkapi, mengurangi, dan menafsirkan kontrak sesuai dengan iktikad baik.

Makna iktikad baik sangat abstrak dan menjadi norma terbuka yang setiap saat dikembangkan oleh hakim melalui putusannya. Akibatnya iktikad baik lebih merupakan produk peradilan daripada legislasi. Penafsiran hakim terhadap iktikad baik tersebut berkembang dalam kasus demi kasus, sehingga sulit untuk menarik kreteria iktikad baik tersebut.

\footnotetext{
137 /bid.

${ }^{138}$ Setiawan. Pengaruh ...Op.Cit. HIm 141

${ }^{139}$ Ibid. HIm 36.
} 


\section{Daftar Pustaka}

Atiyah, P.S. 1981. An Introduction to the Law of Contract. Oxford: Clarendon Press. Atiyah, P.S. 1988. The Rise and Fall of Freedom of Contract. Oxford: Clarendon - Press.

Atiyah, P.S. 1988. Essay on Contract. Oxford: Clarendon Press.

Badrulzaman, Mariam Darus. 1983. KUHPerdata Buku III Hukum Perikatan dengan Penjelasan. Bandung: Alumni.

Beatson, Jack, dan dan Daniel Friedmann - (eds). 1995. Good Faith and Fault in Contract Law. Oxford: Clarendon. Press.

Bloembergen, A.R., et.al. 1995. Rechthandelingen en

Overeenkomst. Deventer: Kluwer.

Berman, Harold J. 1999. Law and Revolution, the Formation of Western Legal Tradition. Cambridge: Harvard University Press. :

Bottomley Stephen; dan Stephen'Parker. 1997. Law in Context. Sydney: The:Federation Press.

Burg, Gr van der. 1999. Buku tentang Perikatan dalam Teori dan Yurisprudensi Negeri Belanda Setelah Perang Dunia II. Saduran F. Tengker dan Wila Chandrawila Supriadi. Bandung: Mandar Maju.

Calamari, John dan Joseph M.Perillo. 1977. Contracts. St. Paul. Minn: West Publishing Company.
Chand, Hari. 1994. Modern Jurisprudence. Kuala Lumpur: International Law Book Services.

Cheseman, Henry R. 1995. Business Law: The Legal, Ethical; and International Environment. New Jersey: Prentice Hall. 2000. Contemporary Business Law. New Jersey: Prentice Hall:

Clark. Roberth W. 1987. Inequality of Bargaining Power, Judicial Intervention in Improvident and Unconsionable Bargain. Toronto: Carwell.

Davidson, Daniel V., et.al. 1987. Comprehensive Business Law. Boston: Kent Publishing $\mathrm{Co}$.

Dillavou, Essel R., et.al. 1964. Principles of Business Law. Engelwood Cliffs, New Jersey: Prentice Hall Inc.

Downes, T. Antony: 1997.Contract. London: Blackstone Limited.

Dunne, van J.M. 1993. Verbintenissenrecht, Deel 1, Contarctenrecht, 1 e gedelte. Deventer: Kluwer.

Dunne, van J.M., dan Gr van der Burght t. "Penyalahgunaan Keadaan." Materi Kursus Hukum Perikatan III (terjemahan Sudikno Mertokusumo). Kerjasama Dewan Kerjasama IImu Hukum Belanda dan Proyek Hükum Perdata Indonesia. Semarang 22 Agustus - 3 September 1988.

Feibleman, James K. 1985. Justice, Law, and Culture. Dordrecht: Martinus Nijhoff.

Fried, Charles. 1981. Contract as Promises, a Theory of Contractual Obligation. 
Cambridge: Harvard University Press.

Fuller, Lon L. dan Melvin Aron Eisenberg. 1972.

Basic Contract Law. West Publishing

Co: St.Paul-Minn.

Gautama, Sudargo. 1993. Himpunan Yurisprudensi Indonesia yang Penting untuk Praktek Sehari-hari (landmark Decisions) Berikut Komentar, Jilid 6. Bandung: Citra Aditya Bakti.

Gillies, Peter. 1993. Business Law. Sydney: The Federation Press.

Graw, Stephen. 1997. An Introduction to the Law of Contract. Sydney: The Law Book Co. Ltd:

Guest. A.G. (ed). 1979. Anson's Law of Contract. Oxford: Clarendon Press.

Guest, A.G. (ed). 1983. Chity. on Contract, Volume I - General Principles. London: Sweet \& Maxwell.

Haanappel P.P.C. dan Ejan Mackaay. 1990. Niewe - Nederlands Burgerlijk Wetboek Het Vermogensrecht. Deventer: Kluwer.

Harahap, M. Yahya. "Dua Sisi Putusan Hakim Tidak Adfil bagi yang Kalah dan Adil bagi yang Menang." Varia Peradilan. Tahun VIII No. 95 (Agustus 1993).

\section{Beberapa Tinjauan tentang} Permasalahan Hukum, Buku Kesatu. Bandung: Citra Aditya Bakti.

Harris, Donald dan Denis Tallon (eds). 1989. Contract Law Today, Anglo-French Comparision. Oxford: Clarendon Press.
Hartkamp, Arthur et.al (eds). Toward a European Civil Code. The Hague: Kluwer, 1998.

Hartkamp, Atrhur S, dan Marianine M.M. Tillema. 1993. Contract Law in the Netherlands. Deventer: Kluwer.

Hondius, Ewoud $H$ (ed). 1991. Precontractual Liability: Report to the XIIIth Congress International Academy of Comparative Law Montreal, Canada 18 - 24 August 1990. Deventer: Kluwer.

Horwitz, Morton J. 1995.The Transformation of American Law, 1780 - 1860. Cambridge: Harvard University Press.

- 1992. The Transformation of American Law 1870 - 1960 The Crisis of Legal Orthodoxy. Cambridge: Oxford University Press.

Klomp, R.J.Q., (red). 1997. Burgerlijk Wetboek, Boeken $1 \mathrm{t} / \mathrm{m}$ 8. Nijmegen: Ars Aequi Libri.

Kusumah-Atmadja, Z. Asikin (ed). 1992. Beberapa Yurisprudensi yang Penting serta Hubungan Ketentuan Hukum Hukum Acara. Jakarta: Mahkamah Agung Republik Indonesia.

Ladbury, R.A. dan I.M. Paterson. "Influence of Continental European Law on Australian Commercial Law." International Business Lawyer. (January 1997).

Latimer Paul. 1997. Australian Business Law. Sydney: CCH Australia Limited.

Lewis, Arthur. 1998. Introduction to Business Law. Wirral: Tudor Business Publishing Ltd. 
Mackendrick, Ewan. 1995. Contract Law. London: Macmillan.

Mahkamah Agung Republik Indonesia. 1972. Yurisprudensi Indonesia. Jakarta: Mahkamah Agung Republik Indonesia.

Merryman, John Henry. 1969. The Civil Law Tradition: An Introduction to the Legal Systems of Western Europe and Latin America. Stanford: Stanford University Press.

Mertokusumo, Sudikno. 1999. Mengenal Hukum. Yogyakarta: Liberty.

Mertokusumo, Sudikno dan A. Pitlo. 1993. BabBạb tentang Penemuan Hukum. Bandung: Citra Adiya Bakti.

Panggabean, Henry. 1992. Penyalahgunaan Keadaan (Misbruik van Omstandigheiden) sebagai Alasan (Baru) Pembatalan Perjanjian. Yogyakarta: Liberty.

Patrik, Purwahid. 1986. Asas /ktikad Baik dan Kepatutan dalam Perjanjian. Semarang: Badan Penerbit Universitas Diponegoro.

, "Perubahan Keadaan dan Iktikad Baik." Penataran Perbandingan Hukum Kontrak. Kerjasama Fakultas Hukum Universitas Kristen Satya Wacana dengan Vrije Universiteit Amsterdam: Salatiga. 19 - 24 Juli 1993.

Pound, Roscoe. 1999. An Introduction to the Philosohpy of Law. New Brunswick: Transaction Publisher.

Rajagukguk, Erman. "Kontrak Bisnis Internasional dan Kaitannya dengan
Analisis Ekonomi terhadap Kontrak." Jurnal Magister Hukum. Vol I No.1 (September 1999).

Ranke, M.E., et.al. (eds). 1995. Europees Contracten. Arhem: Gouda Quint.

Sales, Jaques. "Why Judicial Precedent is a Source of Law in France." International Business Lawyer. (January 1997).

Santoso, Djohari dan Achmad Ali. 1983. Hukum Perjanjian Indonesia. Yogyakarta: Badan Penerbit FH UIl.

Satrio, J. 1995. Hukum Perikatan, Perikatan yang Lahir dari Perjanjian, Buku II. Bandung: Citra Aditya Bakti.

Setiawan. 1992. Aneka Masalah Hukum dan Hukum Acara Perdata. Bandung: Alumni.

-_... "Menurunnya Supremasi Azas Kebebasan Berkontrak." Newsletter. No. 15/IV/Desember 1993.

—, "Kontrak Standar dalam Teori dan Praktek." Varia Peradilan. Tahun IX. No. 103 (April 1994).

___ "Pengaruh Yurisprudensi terhadap Peraturan Perundang-undangan." Varia Peradilan. Tahun VI No. 65 (Februari 1991):

___- "Publikasi Putusan Hakim." Varia Peradilan. Tahun VIII. No. 95 (Agustus 1993).

Simmonds, N.E. Central Isues In Jurisprudence: Justice, Law, and Rights. London: Sweet \& Maxwell, 1986.

Sjahdeini, Sutan Remy. 1993. Kebebasan Berkontrak dan Perlindungan yang 
Seimbang bagi Para Pihak dalam Perjanjian Kredit Bank di Indonesia. Jakarta: Institut Bankir Indonesia.

Starke, J.G., et.al. 1992. Chesire and Fifoot's

Law of Contract. Sydney: Butterworths.

Subekti. 1976. Aspek-Aspek Hükum

Perikatan Nasional. Bandung: Alumni.

1984. Hukum Perjanjian. Jakarta: Intermasa.

Subekti, R. dan R. Tjitrosudibio. 1981. Kitab Undang-Undang Hukum Perdata (terjemahan). Jakarta: Pradnya Paramita.

Sutantio, Retnowulan. "Perjanjian menurut Hukum Indonesia." Varia Peradilan. Tahun V No. 56 (Mei 1990).

Swan, John dan Barry J. Reiter. Contract: Cases and Materials. Canada:Emont Montgomery. 1985.3

Tan Swee Kian, Catherine, dan Tang See Chim. 1987.Contract Law. Singapore: Times Book International.

Tettenborn, A.M. An Introduction to the Law of Obligation. London Butterworths, 1984.

Tumbuan, Fied.B.G. "Kekuatan Mengikatnya Perjanjian dan Batas-batasnya." makalah, Jakarta (Juli 1998).
Upex, Roberth. 1991. Davies on Contract. London: Sweet \& Maxwell.

Waddams, S.M. 1984. The Law of Contract. Toronto: Canada Law Book Inc.

Watt, Benjamin. "Why Frech Law Reject Judial Precedent." International Business Lawyer. (January 1997).

Werf, H.G van der. 1982. Redelijkheid en Billijkheid in het Contractenrecht: Enkele beschouwingen over Goede Trouw, Redelijkheid en Billijkheid in het Huidige en het Komende Contractenrecht. Arhem: Gouda Quint.

Wery, P.L. 1990. Perkembangan Hukum tentang lktikad Baik di Nederland. Jakarta: Percetakan Negara.

Winccup, Michael H. 1990. Contract Law and Practice, The English System and Continental Comparisions. Deventer: Kluwer.

Woon, Walter. Basic Business Law in Singapore. Singapore: Prentice Hall, 1995.

Zweight, Konrad, dan Hein Kotz. 1987. Introduction to Comparative Law Volume II-The Institution of Private Law. Oxford: Clarendon Press.

Burgerlik Wetboek. Editie 1988/1989. Deventer: Kluwer. 1988. 